\title{
Seizures associated with levofloxacin: case presentation and literature review
}

\author{
Alfredo Bellon • Gonzalo Perez-Garcia • \\ John H. Coverdale $\cdot$ Ranjit C. Chacko
}

Received: 24 June 2009 /Accepted: 4 August 2009 /Published online: 26 August 2009

(C) Springer-Verlag 2009

\begin{abstract}
Purpose We present a case of a patient who developed seizures shortly after initiating treatment with levofloxacin and to discuss the potential drug-drug interactions related to the inhibition of cytochrome P450 (CYP) 1A2 in this case, as well as in other cases, of levofloxacin-induced seizures. Methods Several biomedical databases were searched including MEDLINE, Cochrane and Ovid. The main search terms utilized were case report and levofloxacin. The search was limited to studies published in English.

Results Six cases of levofloxacin-induced seizures have been reported in the literature. Drug-drug interactions related to the inhibition of CYP1A2 by levofloxacin are likely involved in the clinical outcome of these cases.

Conclusions Clinicians are exhorted to pay close attention when initiating levofloxacin therapy in patients taking medications with epileptogenic properties that are CYP1A2 substrates.
\end{abstract}

Keywords Fluoroquinolones · Antibiotics · Side effects · Antidepressants $\cdot$ Drug-drug interactions

\section{Introduction}

Levofloxacin is one of the new fluoroquinolones that has been extensively prescribed based on its tolerability. A

\footnotetext{
A. Bellon $(\bowtie)$

Centre de Psychiatrie et Neurosciences, INSERM U894

Laboratoire de Physiopathologie des Maladies Psychiatriques,

Paris, France

e-mail: alfredobellon@yahoo.com

G. Perez-Garcia • J. H. Coverdale • R. C. Chacko

Menninger Department of Psychiatry \& Behavioral Sciences,

Baylor College of Medicine,

Houston, TX, USA
}

recent study reported that levofloxacin is among the safest medications in its class, with an adverse drug reaction rate of only $2 \%$ [1]. Adverse effects involving the central nervous system (CNS) are rare, and when present they include headache, insomnia, agitation, and dizziness [2]. Even more infrequent, but of serious concern, is the occasional appearance of convulsions [2]. There are only five cases of levofloxacin-induced seizures published in English in data bases such as MEDLINE, Ovid, and Cochrane [2-4] (Table 1). Here, we present the case of a patient who had no past history of convulsions and who developed seizures shortly after initiating treatment with levofloxacin. Potential drug-drug interactions taking place in this patient as well as in previously published cases are presented and their clinical implications are discussed.

\section{Methods}

Several biomedical databases were searched including MEDLINE, Cochrane, and Ovid. The main search terms utilized were case report and levofloxacin. The search was limited to studies published in English. The causality assessment of the current case was performed following the Naranjo probability scale [5].

\section{Case report}

A 58-year old woman with no prior psychiatric history, seizure episodes, or neurological problems was admitted to the hospital with spiking fevers up to $39.1^{\circ} \mathrm{C}$. She had a history of chronic pancreatitis, breast cancer, and a total abdominal hysterectomy for dysfunctional uterine bleeding. On the 5th day of hospitalization, psychiatry was consulted due to the patient's lack of motivation and depressed mood. 
Table 1 Case reports of levofloxacin-induced seizures

\begin{tabular}{|c|c|c|c|c|c|}
\hline Reference & Fluoroquinolone & Antidepressant & Other medications & Time to seizure & Clinical History \\
\hline Kushner et al. [3] & $\begin{array}{l}\text { Levofloxacin } \\
500 \mathrm{mg} \text { on day } 1 \\
\text { and } 250 \mathrm{mg} \\
\text { thereafter }\end{array}$ & $\begin{array}{l}\text { Trazodone } \\
\text { (dose not } \\
\text { specified) }\end{array}$ & $\begin{array}{l}\text { Levothyroxine, nabumetone, } \\
\text { risperidone, aspirin, enalapril, } \\
\text { isosorbide dinitrate }\end{array}$ & $\begin{array}{l}\text { Day } 3 \text { of } \\
\text { levofloxacin }\end{array}$ & $\begin{array}{l}75 \text { years; lower } \\
\text { limb ischemia }\end{array}$ \\
\hline Kushner et al. [3] & $\begin{array}{l}\text { Levofloxacin } \\
500 \mathrm{mg} \text { daily }\end{array}$ & $\begin{array}{l}\text { Sertraline } \\
50 \mathrm{mg} \text { daily }\end{array}$ & $\begin{array}{l}\text { Nebulized albuterol, milk of } \\
\text { magnesia, cascara, alendronate, } \\
\text { haloperidol, sorbitol, donepezil, } \\
\text { benztropine, famotidine }\end{array}$ & $\begin{array}{l}\text { Day } 5 \text { of } \\
\text { levofloxacin }\end{array}$ & $\begin{array}{l}74 \text { years; bacterial } \\
\text { pneumonia with } \\
\text { pleural effusions }\end{array}$ \\
\hline Christie et al. [2] & $\begin{array}{l}\text { Levofloxacin } \\
500 \mathrm{mg} \text { daily }\end{array}$ & $\begin{array}{l}\text { Paroxetine } \\
5 \mathrm{mg} \text { daily }\end{array}$ & $\begin{array}{l}\text { Prednisone, warfarin, folic acid, } \\
\text { levothyroxine }\end{array}$ & $\begin{array}{l}\text { Approximately } \\
7 \mathrm{~h} \text { after first } \\
\text { dose of } \\
\text { levofloxacin }\end{array}$ & $\begin{array}{l}87 \text { years; } \\
\text { unresponsiveness }\end{array}$ \\
\hline Bird et al. [4] & $\begin{array}{l}\text { Levofloxacin } \\
500 \text { mg daily }\end{array}$ & $\begin{array}{l}\text { Citalopram } \\
40 \text { mg daily }\end{array}$ & $\begin{array}{l}\text { Donepezil, aspirin, doxazosin, } \\
\text { folate, gabapentin, divalproex } \\
\text { sodium, ranitidine }\end{array}$ & $\begin{array}{l}\text { Approximately } \\
\text { after day } 4 \text { of } \\
\text { levofloxacin }\end{array}$ & $\begin{array}{l}75 \text { years; seizure } \\
\text { disorder, renal } \\
\text { insufficiency and } \\
\text { Alzheimer's disease }\end{array}$ \\
\hline Bird et al. [4] & $\begin{array}{l}\text { Levofloxacin } \\
500 \text { mg daily }\end{array}$ & Not specified & Donepezil & Day 5 of levofloxacin & 74 years; not specified \\
\hline Current case & $\begin{array}{l}\text { Levofloxacin } \\
500 \text { mg daily }\end{array}$ & $\begin{array}{l}\text { Mirtazapine } \\
15 \mathrm{mg} \text { daily }\end{array}$ & $\begin{array}{l}\text { Enoxaparin, metoclopramide, } \\
\text { nystatin suspension, pantoprazole }\end{array}$ & $\begin{array}{l}\text { Approximately } 5 \mathrm{~h} \\
\text { after first dose of } \\
\text { levofloxacin }\end{array}$ & $\begin{array}{l}58 \text { years; pancreatitis, } \\
\text { Klebsiella bacteremia }\end{array}$ \\
\hline
\end{tabular}

The patient acknowledged feeling depressed and anxious and attributed this to the uncertain etiology of her pancreatitis as well as the unclear origin of her fever. She also reported poor sleep, poor appetite, low energy, and low concentration. Due to concerns about her lack of appetite and sleep, mirtazapine $7.5 \mathrm{mg}$ orally at bedtime was started. Her other medications at the time included metoclopramide $10 \mathrm{mg}$ orally once a day, cefepime $1 \mathrm{~g}$ intravenous every $12 \mathrm{~h}$, pantoprazole $40 \mathrm{mg}$ orally once a day, and acetaminophen $500 \mathrm{mg}$ orally in case of fever or pain. She tolerated this initial mirtazapine dose, which was increased to $15 \mathrm{mg}$ orally at bedtime on the 9th day of admission. The following day, her temperature appeared to be under control. She had a maximal temperature of $37.8^{\circ} \mathrm{C}$ which contrasted with previous values of up to $39.9^{\circ} \mathrm{C}$. On her 10th day in the hospital, she developed a rash to cefepime and the infectious diseases team changed the medication to levofloxacin $500 \mathrm{mg}$ orally once a day.

The first dose of levofloxacin was given the afternoon of the 11th day of hospitalization. That evening, the patient lost consciousness and bowel control concomitantly. In the early morning of the 12th day of admission, the patient's family reported seizure activity consisting of approximately $30 \mathrm{~s}$ of upper-extremity tonic-clonic contractions and loss of bowel control. The patient could not remember these events afterward. The second dose of levofloxacin was given a few hours later, and shortly after, seizure activity was noted by the registered nurse. In this episode, the patient's head turned to one side, she began foaming at the mouth, and her eyes rolled back. She again showed tonicclonic contractions of her upper and lower extremities and lost bowel control. Immediately after the seizure, she was not oriented to place and could not provide her family members' names. Her medications at the time were levofloxacin $500 \mathrm{mg} /$ day orally, enoxaparin $40 \mathrm{mg} /$ day subcutaneous, metoclopramide $10 \mathrm{mg}$ orally before each meal, mirtazapine $15 \mathrm{mg}$ /day orally, nystatin suspension $5 \mathrm{ml} /$ day orally, pantoprazole $40 \mathrm{mg}$ /day orally, and acetaminophen $500 \mathrm{mg}$ orally in case of fever or pain.

The patient was transferred to the intensive care unit for workup of her seizures. Mirtazapine and levofloxacin were discontinued, and the patient was started on fosphenytoin for seizure control as well as aztreonam for her infection. On the morning of the 12th day, her complete blood count showed white blood cells $10.8 \times 10^{9} / \mathrm{L}$ with $86 \%$ neutrophils, hemoglobin $9.4 \mathrm{~g} / \mathrm{dl}$, hematocrit $30.2 \%$, and platelets $553 \times 10^{9} / \mathrm{L}$. A metabolic panel was within normal limits except for sodium of $133 \mathrm{mEq} / \mathrm{L}$ and chloride of $96 \mathrm{mEq} / \mathrm{L}$. Her calcium was $6.8 \mathrm{mg} / \mathrm{dl}$, although after correction with an albumin of $2.9 \mathrm{~g} / \mathrm{dl}$, the calcium level was $7.68 \mathrm{mg} / \mathrm{dl}$. Moreover, her ionized calcium level taken the very next day was within normal limits $(1.15 \mathrm{mmol} / \mathrm{L})$. Likewise, her magnesium and phosphorus were normal. Her thyroidstimulating hormone level and computed tomography (CT) of the head were unremarkable, and her abdominal CT showed no changes and no abscesses. Her cerebrospinal fluid (CSF), urine cultures, and cryptococcal antigen were negative, and her CSF venereal disease research laboratory test was nonreactive. In contrast, Klebsiella bacteremia was 
found. No further seizure activity was reported, and she was discharged home after 14 days in the hospital.

\section{Discussion}

Electrolyte abnormalities are well recognized causes of convulsions. In this case, however, it is unlikely that this patient's serum sodium of $133 \mathrm{mEq} / \mathrm{L}$ had been the source of convulsant activity, as patients in most instances remain asymptomatic, even with sodium levels as low as $125 \mathrm{mEq} / \mathrm{L}$. Her calcium levels were also unlikely to be implicated, because even though her serum calcium remained slightly low after albumin correction, her ionized calcium was within normal limits.

The epileptogenic nature of fever is also well recognized. Nevertheless, in this case, it does not appear to be a determinant factor considering this patient had body temperatures of up to $39.9^{\circ} \mathrm{C}$ without associated convulsions on several occasions before treatment with levofloxacin was initiated. Additionally, on the day of her first levofloxacin dose, her body temperature was measured on four different occasions and was never above $38.3^{\circ} \mathrm{C}$.

In contrast to the lack of a direct association among electrolyte abnormalities and fever with this patient's convulsions, there is a clear temporal relationship between the initiation of levofloxacin and the appearance of seizures. In fact, levofloxacin can readily cross the blood-brain barrier [6], and thus its effects in the CNS can be rapidly observed. In this case, seizures appeared only $5 \mathrm{~h}$ after the initial levofloxacin dose. There is another report in the literature of levofloxacin-induced seizures merely $7 \mathrm{~h}$ after the first dose [2], whereas the other four cases so far reported resulted in convulsions some days after starting this antibiotic (Table 1)

The mechanism of action by which fluoroquinolones induce seizures remains poorly understood. It has been related to the ability of these antimicrobials to either antagonize the inhibitory effect of gamma-aminobutyric acid (GABA) [6-8] or to its capacity to activate the Nmethyl-D-aspartate (NMDA) receptors [6, 9]. Most likely, the epileptogenic properties arise from a combination of both mechanisms.

Previous reports of fluoroquinolone-induced seizure activity have suggested that the elderly and patients with decreased renal function are at a higher risk [3]. In this case, however, these factors do not apply. The patient was not elderly and had an estimated creatinine clearance of $85 \mathrm{ml} / \mathrm{mg}$ [10]. Consequently, the dose of levofloxacin used is within the range recommended by the current guidelines [11]. The origin of seizures in this case was likely levofloxacin epileptogenic properties. Nonetheless, a drugdrug interaction cannot be totally excluded. According to the Naranjo probability scale [5], levofloxacin was a "probable" cause of seizures in this patient, whereas it is only "possible" that a drug-drug interaction would have caused them. Nonetheless, we believe it is worth reviewing potential drug-drug interactions associated with fluoroquinolones.

When antibiotics within this family and nonsteroidal antiinflammatory drugs (NSAIDs) such as aspirin are combined, the likelihood of seizures increases [12, 13], apparently due to $\mathrm{GABA}_{\mathrm{B}}$ receptor antagonism [6,7]. This drug-drug interaction could have contributed to levofloxacin-induced seizures in two previous cases (Table 1) [3, 4]. It is also known that the epileptogenic risk increases when fluoroquinolones are conjointly prescribed with theophylline $[8,14]$. This is the result of fluoroquinolones eliciting CYP1A2 inhibition [14], which leads to a reduced theophylline clearance and also because theophylline potentiates fluoroquinolone excitatory capacity [8]. Theophylline was not involved, however, in any of the cases of levofloxacininduced seizures (Table 1), but it clearly exemplifies the relevance of CYP1A2 inhibition by fluoroquinolones. A drug relevant for the current case is metoclopramide. Metoclopramide, a medication capable of inducing seizures in overdose [15], is metabolized through CYP1A2 and CYP2D6 [15]. Hence, levofloxacin inhibition of CYP1A2 could have contributed to the appearance of convulsions by exposing our patient to high levels of metoclopramide. A similar mechanism could have occurred with mirtazapine, an antidepressant recently associated with seizures $[16,17]$ and the metabolism of which depends on CYP1A2, 2D6, and $3 \mathrm{~A} 4[15,18]$. Despite the three enzymes involved in its clearance, the inhibition of only CYP1A4 can elicit more than a two-fold increase of mirtazapine serum concentration [18].

Interestingly, all the cases published in the English literature of seizures related to levofloxacin have been in patients taking some form of the new generation of antidepressants [2-4] (Table 1). There is only one case in which the patient's medications and medical conditions were not specified so that the link between antidepressants and levofloxacin cannot be established [4] (Table 1). Information about the effect of psychotropic medications on seizure threshold is still not specific and is difficult to translate into clinical practice. However, a consensus has been reached on which of these drugs possess a higher risk and which possess a lower risk in inducing seizure activity [19]. The antidepressants used concomitantly in the levofloxacin-induced seizure cases, including mirtazapine, trazodone, paroxetine, and sertraline (Table 1), are among the psychotropics that exhibit a low risk. Only mirtazapine is a substrate of CYP1A2 [15]. Therefore, their role in the cases of levofloxacin-induced seizures is yet to be established.

Another plausible explanation for the outcome of at least some of the cases presented in Table 1 comes from CYP1A2 substrates with no epileptogenic effects, such as 
nabumetone [20] and haloperidol [21], which could augment the concentration of levofloxacin and consequently increase patients' susceptibility to seizures. Nonetheless, it has to be kept in mind that drug-drug interactions originate at various pharmacodynamic and pharmacokinetic levels and that drugs CYP affinities are seldom completely CYP-specific, thus levofloxacin may have drug interactions at the level of CYPs other than CYP1A2.

To conclude clinicians are advised to closely attend to the possibility of seizures initiated by levofloxacin when patients are taking other medications with epileptogenic properties that are CYP1A2 substrates, such as mirtazapine, metoclopramide, and theophylline.

Acknowledgements $\mathrm{AB}$ receives financial support from the Fondation de la Recherche Medicale, France, CONACYT scholarship \#74641 and the Young Minds in Psychiatry Award given by the American Psychiatric Association.

\section{References}

1. Carbon C (2001) Comparison of side effects of levofloxacin versus other fluoroquinolones. Chemotherapy 47(Suppl 3):9-14 discussion $44-18$

2. Christie MJ, Wong K, Ting RH, Tam PY, Sikaneta TG (2005) Generalized seizure and toxic epidermal necrolysis following levofloxacin exposure. Ann Pharmacother 39(5):953-955

3. Kushner JM, Peckman HJ, Snyder CR (2001) Seizures associated with fluoroquinolones. Ann Pharmacother 35(10):1194-1198

4. Bird SB, Orr PG, Mazzola JL, Brush DE, Boyer EW (2005) Levofloxacin-related seizure activity in a patient with Alzheimer's disease: assessment of potential risk factors. J Clin Psychopharmacol 25(3):287-288

5. Naranjo CA, Busto U, Sellers EM, Sandor P, Ruiz I, Roberts EA, Janecek E, Domecq C, Greenblatt DJ (1981) A method for estimating the probability of adverse drug reactions. Clin Pharmacol Ther 30(2):239-245

6. Akahane K, Kato M, Takayama S (1993) Involvement of inhibitory and excitatory neurotransmitters in levofloxacin- and ciprofloxacin-induced convulsions in mice. Antimicrob Agents Chemother 37(9):1764-1770

7. Akahane K, Tsutomi Y, Kimura Y, Kitano Y (1994) Levofloxacin, an optical isomer of ofloxacin, has attenuated epileptogenic activity in mice and inhibitory potency in GABA receptor binding. Chemotherapy 40(6):412-417

8. Segev S, Rehavi M, Rubinstein E (1988) Quinolones, theophylline, and diclofenac interactions with the gamma-aminobutyric acid receptor. Antimicrob Agents Chemother 32(11):1624-1626

9. Schmuck G, Schurmann A, Schluter G (1998) Determination of the excitatory potencies of fluoroquinolones in the central nervous system by an in vitro model. Antimicrob Agents Chemother 42 (7):1831-1836

10. Jelliffe RW (1973) Letter: Creatinine clearance: bedside estimate. Ann Intern Med 79(4):604-605

11. Gilbert DN, Moellering RC, Eliopoulos GM et al (2008) The Sanford guide to antimicrobial therapy. Antimicrobial Therapy, Stowe

12. Hori S, Kizu J, Kawamura M (2003) Effects of anti-inflammatory drugs on convulsant activity of quinolones: a comparative study of drug interaction between quinolones and anti-inflammatory drugs. J Infect Chemother 9(4):314-320

13. Shrivastava MP, Makde SD, Paranjpe BD (1997) Interaction of ciprofloxacin with diclofenac and paracetamol in relation to it's epileptogenic effect. Indian J Physiol Pharmacol 41 (2):164-166

14. Nakamura H, Ohtsuka T, Enomoto H, Hasegawa A, Kawana H, Kuriyama T, Ohmori S, Kitada M (2001) Effect of levofloxacin on theophylline clearance during theophylline and clarithromycin combination therapy. Ann Pharmacother 35 (6):691-693

15. Fuller MA, Sajatovic M (2004) Drug information handbook for psychiatry. Lexi-Comp's, Canada

16. Zia Ul Haq M, Prakash R, Akhtar S (2008) Mirtazapine precipitated seizures: a case report. Prog Neuropsychopharmacol Biol Psychiatry 32(4):1076-1078

17. Spyridi S, Sokolakia S, Siamoulia M et al (2007) Status epilepticus in a patient treated with olanzapine and mirtazapine. Eur Psychiatr 22(Suppl 1):S163

18. Bachmann KA, Lewis JD, Fuller MA et al (2004) Drug interactions hand book. Lexi-Comp's, Canada

19. Pisani F, Oteri G, Costa C, Di Raimondo G, Di Perri R (2002) Effects of psychotropic drugs on seizure threshold. Drug Saf 25 (2):91-110

20. Turpeinen M, Hofmann U, Klein K, Murdter T, Schwab M, Zanger UM (2009) A predominate role of CYP1A2 for the metabolism of nabumetone to the active metabolite, 6-methoxy-2naphthylacetic acid, in human liver microsomes. Drug Metab Dispos 37(5):1017-1024

21. Fang J, McKay G, Song J, Remillrd A, Li X, Midha K (2001) In vitro characterization of the metabolism of haloperidol using recombinant cytochrome p450 enzymes and human liver microsomes. Drug Metab Dispos 29(12):1638-1643 